folk/ed. Derg, 2021; 27(4)-108. sayı

DOI: $10.22559 /$ folklor.1823

Araştırma makalesi/Research article

\title{
Hekimlik Mesleğine Illk Geçiş Riti: Beyaz Önlük Giyme
}

\section{The First Rite of Transition to the Medical Profession: Wearing a White Coat}

Aslı Büyükokutan Töret*

Öz

Tip fakültesini kazanan öğrencilerin mesleğe kabullerinin bir göstergesi olan beyaz önlük giyme, hekimlik mesleğindeki ilk geçiş ritidir. Öğretim üyeleri tarafindan öğrencilere beyaz önlük giydirilen, hekimlik andı okunan tören, kokteyl ve fotoğraf çekimlerinin ardından sona ermektedir. Yazıda, Eskişehir Osmangazi Üniversitesi Tıp Fakültesi hekimleri, öğrencileri ve öğrencilerin aileleriyle yapılan görüşmelerden hareketle, hekimlik mesleğindeki Beyaz Önlük Giyme Töreni üzerinde durulmuştur. Törende beyaz önlüğün öğretim üyeleri tarafindan öğrencilere giydirilmesi ve hekimlik andının edilmesi uygulamaları yapısal ve işlevsel özellikleriyle ele alınmıştır. Tespit ve değerlendirmeler sonucunda törenin, hekim adaylarının hekimlik mesleğine kabulü açısından işlevsel olduğu görülmüştür. Öğretim üyeleri, öğrencilere beyaz

Geliş tarihi (Received): 13-04-2021 - Kabul tarihi (Accepted): 25-07-2021

* Doç.Dr., Eskişehir Osmangazi Üniversitesi Fen-Edebiyat Fakültesi Türk Dili ve Edebiyatı Bölümü. (Eskişehir Osmangazi University Faculty of Arts and Sciences Department of Turkish Language and Literature) abuyukokutan@hotmail.com. ORCID 0000-0001-8732-6043 
önlüklerini giydirirken onları tebrik edip hekimlik mesleğine girişlerini kutlamaktadır. Kendine özgü kuralları ve düzeni olan törenin her yıl tekrarlanması; sürekliliğin sağlanması ve öğrencilere tıp etiği kurallarının aktarılması açısından işlevseldir. Tıp mesleğinin ulviliğine ve sağlığın kutsiyetine dair konuşmalarla öğrencilerin hekim kimliğinin oluşması sağlanmaktadır. Hekimlik andı ile öğrenciler duygudaş olmaktadır. Çocuklarının saygın bir mesleğe törenle girişini tecrübe eden aileler de gururlanmakta, birbirleriyle duygusal manada hemhâl olmaktadır.

Anahtar sözcükler: Eskişehir, Tıp fakültesi, beyaz önlük giyme töreni, hekimlik mesleği, rit

\begin{abstract}
Wearing a white coat, which represents the acceptance of the medical school students to the profession, is the first transition rite in the medicine. The ceremony, where faculty members dressed students up in white coats, and the Hippocratic oath is read, ends after a cocktail and photoshoot. The article focuses on the White Coat Ceremony in the medical profession, based on interviews with Eskişehir Osmangazi University Faculty of Medicine physicians, students, and their families. In the ceremony, the practices of dressing the students in the white coat by the faculty members and Hippocratic oath were discussed with their structural and functional characteristics. As a result of the determinations and evaluations, it has been seen that the ceremony is functional in terms of the acceptance of physician candidates to the profession. Faculty members congratulate students on their entry into the medical profession while dressing them in their white coats. The annual repetition of the ceremony, which has its own rules and order, is functional in terms of ensuring continuity and transferring the rules of medical ethics to the students. It is ensured that the physician identity of the students is formed by the speeches about the sublimity of the medical profession and the sanctity of health. Students become empathetic with the Hippocratic oath. Families who experience the ceremonial entry of their children into a respected profession are proud as well, and they agree with each other emotionally.
\end{abstract}

Keywords: Eskişehir, Faculty of Medicine, white coat ceremony, medical profession, rite

\title{
Extended summary
}

In addition to birth, marriage, and death rituals, there are participant acceptance rituals in human life. The secret acceptance in the context of the profession, and the acceptance of a profession which includes a high-level society statue of individuals, the acceptance ritual to the required profession, is one of these rituals. In this sense, the transition to the medical science profession, which is an archaic profession, is attention-grabbing in terms of its ritualistic dimension. The ritual known as the "White Coat Ceremony" is the first rite seen in the medical science profession. The ceremony of wearing a white coat represents the transition of the freshman students to the medical science profession. Right alongside the 
students, families, and relatives, members of the medicine faculty, the dean, and the warden of the university participate in the ceremony. Each faculty member dressed the white coats to the students, who are composed of a specific number of groups. After wearing the white coats, the students swear a vow, which is based on the Hippocratic oath, in unison. There is a collective photoshoot with the white coats at the end of the ceremony.

In the article, the White Coat Ceremony in the medical profession was emphasized based on the interviews made with the physicians of Eskişehir Osmangazi University Faculty of Medicine, students, and families of the students. The impact and meaning of the White Coat Ceremony on students and faculty members were questioned by considering its structural, and functional features. As a result of this inquiry, it was seen that the ceremony of wearing white coats was a transitional rite that welcomed students who had enrolled in medical education, celebrated their entry into the medical community, attributed them a new identity and aimed at embracing this professional identity, and realizing their responsibilities from day one. Although there is no professional transition to the practice of medicine, the ceremony, which incorporates students into the medical profession, basically focuses on two symbols. The first symbol of these is that the persons who practice their profession professionally, dressed the white coats to the students. The construction of professional identity begins with the conversations about the meanings that are represented with the white coat, the sanctity, and the history of medicine. In this identity-building process that will continue throughout the medical school, the message that the faculty directors and faculty members will be with the students is given by the participation of these people in white coats in the ceremony. With white coats dressed by the professionals who practice their profession, students are accepted among their colleagues, even though as students. And the second symbol is the reading of a vow, similar to the Hippocratic oath, in which each institution organizes its contents in its own way. This oath, which was taken at the beginning of medical education as Hippocrates did, is an indication that the students accept the ethical values of medicine in the presence of all participants.

Although the history of the ceremony, which was the first transition to the profession of medicine, does not go back a long time, the current rules, accepted orde, and the reading of the vow of medicine that connects medical students to the profession gives the impression that the tradition, has been done since time immemorial. The term "traditional" is used to describe the ceremony, and the emphasis on tradition in the opening speeches suggests to the participants that the White Coat Ceremony dates back a long time. A positive opinion has been given regarding the vow of medicine read at the ceremony in a way that the ceremony works. The content of the medicine vow that is read in the White Coat Ceremony of Eskişehir Osmangazi University, is accepted as international values by both the faculty members and the students. It is stated that there is a text describing the requirements of medicine, there is no disturbing sentence in it, and it is traditional, so it is a writing that no one will consider changing. It is stated that the text does not show discrimination between different religions, languages, and nationalities, and it is read in order to make students feel as if they are doctors at the beginning of their journey. The ceremony which is described 
as the "welcome aboard ceremony", is asked to continue in order for it to gain a seat as a nice memory in addition to the functions of building responsibilities, promoting, aspiring, and motivating the students.

\section{Giriş}

Toplumlar, üyelerinin hayatlarındaki dönemleri birbirinden ayırırlar. Bu ayrım, bireylerin kişisel ve toplum içindeki yerinin ve konumunun değiştiği bazı dönemlere göre yapılır. Toplumdan topluma değişkenlik göstermekle birlikte işlevin özünü koruduğu birtakım tören ve kutlamaların eşlik ettiği bu dönemlerde bireyler, bir yaşam basamağından diğerine geçerler. Diğer bir ifadeyle, hâli hazırda dâhil oldukları toplumdan farklılaşan bazı hak ve sorumluluklara sahip olurlar. Birey için bir statüden diğerine geçişi ve kabulü sembolize eden bu süreç, geçiş/giriş dönemi olarak adlandırılır ve bünyesinde birçok kültürel unsuru ve inancı barındırır.

Doğum, evlilik, ölüm ve üyeliğe kabul dönemleri insan yaşamının en önemli ve evrensel nitelikli geçiş dönemleridir (Karaman, 2010: 231). Bireyin bu geçiş dönemindeki yeni statüsünü belirlemek, kutsamak, kutlamak, aynı zamanda da onu bu sırada yoğunlaştığına inanılan tehlikelerden ve zararlı etkilerden korumak amacıyla çeşitli ritüeller düzenlenmektedir (Örnek, 2016: 183). Yüksek toplumsal statü içeren tıp mesleğine kabulün gereği yapılan Beyaz Önlük Giyme riti de bu bağlamda dikkat çekicidir. Tıp fakültesine başlayan öğrencilerin mesleğe girişlerini kutlayan, meslekleri ile ilgili farkındalık yaratan, onları meslektaşlarıyla buluşturan, diğer bir ifadeyle tıp çatısı altına alan bu tören, hekimlerin mesleki hayatlarındaki ilk geçiş ritidir. Tıp mesleğinin Beyaz Önlük Giyme ritinden söz etmeden önce ritüel ve rit kavramları üzerinde kısaca durmakta yarar vardır.

Ritüel kavramıyla ilgili yapılmış tanımlamalar incelendiğinde, bazı kaynaklarda ritüel ve rit kavramları birbirinin yerine kullanılırken bazılarında kavramların farklı tanımlarının yapıldığı görülmektedir. ${ }^{1}$ Rit, "Dinsel anlamda belirli bir cemaatin uyguladığı törenler, sosyolojik anlamda ise bir sosyal grubun günlük yaşam ve tören pratiklerini de kapsayan alışkanlık hâlindeki davranma biçimleri”, ritüel ise topluluk ya da dinsel cemaatlerin törenlerinde uyguladıkları ritler bütünü olarak tanımlanmaktadır (Bilgin, 2003: 312). Dolayısıyla ritüel, ritleri de içine alan bir çatı konumundadır. Ritüel üzerine çalışmalar yapan antropolog ve sosyologlar ritüelin resmiyet, geleneksellik, değişmezlik, kuralcılık, kutsal sembolizmi ve performans özelliği üzerinde durmuşlardır (Connerton, 2014: 76-83; Çilingir Cesur, 2020: 23-28).

Ritüellerin, sadece ilkel toplulukların dinsel tören ve kuralları olmadığı, dinden bağımsız nitelikte ve modern toplumlarda da bulunduğu tespit edilmiştir (Özbudun, 1997: 26; Karaman, 2010: 229). Ritüelin bir gücü olduğu, bireylerin daha güçlü hissetmesini sağlamanın dışında onları güçlendirdiği, sosyal birleşmenin temelinin bu davranışlarda yattığı belirtilmektedir (Çilingir Cesur, 2020: 51). Bu bağlamda Beyaz Önlük Giyme riti de tıp fakültesine yeni adım atan öğrencileri tıp çatısı altına alarak onları birbirine ve tıp ailesine bağlayan bir yapı sergilemektedir. Emile Durkheim'ın yaklaşımına göre ritüeller, bir yandan da kutsal ile bağlantılı olduğundan kutsalın karşısında bireyin nasıl davranacağını belirleyen kurallar silsilesidir (Bloch, 2014: 44). 
Yapı olarak ritüeller, uygun zamanlarda bazı aleni değerlerin yanı sıra kişi ya da gruplarla alakalı bazı değerlerin, değişmez bir üslûpla tekrarlanması özellikleriyle öne çıkmaktadır (Honko, 2006: 130-131). Beyaz Önlük Giyme ritüeli de 1993 yılından beri tekrar edilerek bu sürekliliği yansıtmaktadır. Ritüellerin bünyesinde anlamlı semboller bulunur. Sembollerin ritüelde kullanılması, onların ne kadar etkili olduğunu göstermekle birlikte bu semboller, ritüel performansına katılan kişileri de değiştirir (Çilingir Cesur, 2020: 71). Hekimlik andının, Beyaz Önlük Giyme ritüelinde okunması, katılımcıların dâhil oldukları topluluğa farkındalıklarının artmasında etkili olmaktadır. Ritüelin gerçek anlamının sembolik olduğu ve asıl işlevinin zihinsel olduğu öne sürülür (Segal, 2012: 182).

Ritüellerin icrası sırasında bir otoriteye ya da yol gösterene ihtiyaç duyulmaktadır. Ancak ritüel sırasında ortaya konan mesajla taşıyıcı ve alıcılar tek vücut olur (Rappaport, 2003: 399). Beyaz Önlük Giyme Töreni’nde öğretim üyeleri otoritedir, yol göstericidir. Tören esnasında hekimlik mesleğine ve tıp etiğine dair konuşmalarla, okunan hekimlik andıyla öğretim üyeleri ve öğrenciler arasında birliktelik oluşur.

Ritüellerin yapısal özelliklerinin yanında işlevleri de çalışmalarda sıkça ele alınmıştır. Grup bilincini ve birlikteliğini yükseltmesi (Cohen, 1999: 54), insanların önemli ve gerekli bulduğu şeyi söylemelerine aracılık etmesi (Schuyt ve Schuijt, 1998: 400), toplumsal düzenin sağlanması açısından önemli işlevleri olduğu belirtilmiştir (Karaman, 2010: 232). Ritüel kavramı ile ilgili çeşitli bakış açılarını, ritüellerin yapısal ve işlevsel özellikleri hakkındaki görüşleri detaylı olarak izah etmek, elbette mümkündür. Kanaatimizce, konuyla ilgili açıklamaları, Eskişehir Osmangazi Üniversitesi Tıp Fakültesi öğretim üyeleri, öğrencileri ve öğrencilerin ailelerinden elde edilen bilgiler ile törenin YouTube kanalında paylaşılan video kayıtları 1şığında, hekimlik mesleğine geçiş ritüeli niteliğindeki Beyaz Önlük Giyme Töreni üzerinden sürdürmekte yarar vardır. Hekimlik mesleğinin söz konusu ritüelistik boyutuna dair tespit ve değerlendirmelere geçilmeden önce çalışmanın yöntemi ve önemi hakkında bilgi vermek yerinde olacaktır.

\section{1. Çalışmanın yöntemi}

2019 yılı aralık ayında Çin'in Wuhan kentinde tespit edilmesinin ardından dünya ölçeğinde hızlı ve yıkıcı bir yayılım gösteren ve Türkiye'de de bu doğrultuda görülen ilk vakası 11 Mart 2020 tarihinde açıklanan, yeni tip koronavirüs (COVID-19) salgını nedeniyle çalışma, ağırlıklı olarak elektronik kültür ortamında gerçekleştirilen alan araştırmasına dayanmaktadir.

Bu bağlamda, Eskişehir Osmangazi Üniversitesi Tıp Fakültesi'nde görev yapan ve Beyaz Önlük Giyme Töreni’ne katılmış öğretim üyeleri, öğrenciler ve öğrencilerin aileleri ile derinlemesine mülakat yapılmıştır. Konuyla ilgili farklı bakış açılarını tespit edebilmek ve sağlıklı çözümlemeler yapabilmek adına farklı statü ve konumda bulunan hekimler ile başka üniversitelerde beyaz önlük giymiş olan asistan hekimlere ulaşılmıştır. Araştırmaya veri sağlayan hekimlerin, öğrencilerin ve ailelerin seçilmesinde herhangi bir sınırlamaya gidilmemiştir. Yoğun çalışma saatleri nedeniyle görüşmeye zaman ayırabilecek hekimler 
ve tıp fakültesi öğrencileri ile görüşülebilmiştir. Öğrencilerin ailelerine de yine öğrenciler aracılığıyla ulaşılabilmiştir. Kendisi de aynı tıp fakültesinde öğretim üyesi olan eşimin desteği ile yeterli veri elde edilebilmiştir.

Görüşmeye müsait olan öğretim üyeleri, asistan hekimler, intörn hekimler, öğrenciler ve aileleri ile Zoom programı aracılığıyla gerçekleştirilen görüntülü ve sesli görüşmeler, ağırlıklı olarak akşam saatlerinde kimi zaman da öğle aralarında yapılmıştır. Sağlık, uygulama ve araştırma hastanesi olması nedeniyle hasta sayısının yanı sıra derslerin ve toplantıların da fazla olduğu tıp fakültesinde bazı hekimler, çalışmaya zaman ayıramayacaklarını belirtmişlerdir. Bu durum tarafımızca anlayışla karşılanmış ve görüşme için ısrar edilmemiştir.

Kayıtların deşifresinde, yüksek lisans öğrencim Tuğçe Özdemir'in desteği önemlidir. Kendisine teşekkürü bir borç bilirim. Kaynak kişilerin tamamı, kimlik bilgilerinin yazıda yer almasında bir sakınca olmadığını belirtmiş, kendilerinden metin içinde KK-1, KK-2 şeklindeki kodlamalarla söz edilmiş, yazının sonunda yer alan sözlü kaynaklar kısmında ise açıklayıcı bilgilere yer verilmiştir. Bu kişilerden sekizi Eskişehir Osmangazi Üniversitesi Tıp Fakültesi'nde öğretim üyesi, dördü araştırma görevlisi doktor, biri öğrenci, biri intörn doktor, üçü Eskişehir Osmangazi Üniversitesi Tıp Fakültesi Beyaz Önlük Giyme Töreni'ne katılan ebeveyn, biri de Hacettepe Üniversitesi Tıp Fakültesi'nden emekli öğretim üyesidir.

\section{2. Çalışmanın önemi}

Yirminci yüzyılın ilk çeyreğinden ortalarına kadar olan süreçte endüstriyel gelişim paralelinde değişen sosyal doku ve yaşantılar neticesinde halk bilimciler yeni alan ve konular üzerine yönelmiş, folklor ürünlerinin sadece kırsal yaşantılarda değil kentsel yaşantılar içerisinde de takip edilebileceği anlaşılmıştır (Aça, 2020: 26). Sahanın genişlemesiyle birlikte çeşitli meslek grupları da araştırma konusu edilmeye başlanmıştır. Türkiye merkezli folklor araştırmaları içinde Giresun ve Trabzon illeri balıkçılık kültürünü, kapsamlı bir şekilde ele alması nedeniyle kültürel bağlamlı çalışmalara model oluşturan, yeni araştırma konularının ve bakış açılarının geliştirilmesine katkı sağlayan ilk çalışma Mustafa Aça tarafından yapılmıştır. 2014 yılında tamamlanan doktora tezi, 2020 yılında "Denizin Çocukları. Giresun ve Trabzon Yöresi Balıkçılarının Meslek Folkloru” adıyla kitap olarak yayımlanmıştır (Aça, 2020).

Tarihsel süreç içerisinde meslek folklorunun gelişim çizgisine ve meslek folkloru çalışmalarına bakıldığında ${ }^{2}$, hekim folkloruyla ilgili çalışmaların sınırlı sayıda olduğu dikkat çekmektedir. ${ }^{3}$ Hekimlik mesleği, en eski meslek gruplarından biri olmasına ve mesleğin icrac1larının tarihin her döneminde toplumda saygın ve yüksek bir statüye sahip rağmen ritüelistik boyutu üzerindeki çalışmalar yok denecek kadar azdır. Bu noktada, Pınar Karataş’ın (2017), Ankara ilinde görev yapan ve Sağlık Bakanlığı'na bağlı kamu kurum ve kuruluşlarında çalışan hekimlerden elde ettiği verilere dayanan "İnsanlar İkiye Ayrılır: Meslek Folkloru Bağlamında Hekimlik" başlıklı çalışması tıp mesleğinin icracıları olan hekimlerin folklorunun farklı boyutlarına değinen, geniş kapsamlı bir çalışma olması açısından önemlidir. Eserin, “Hekim Folkloru” başlıklı üçüncü bölümünde, "Meslek Ritüelleri” başlığı altında beyaz önlük törenine de değinilmektedir. 
Karataş'ın, 2016 yılında doktora tezi olarak hazırladığı söz konusu çalışmanın verilerinden hareketle, hekim folklorundaki stereotipler ve lakaplar üzerine bir makalesi de bulunmaktadır (Karataş, 2017b: 129-142). Farklı örneklem gruplarından hareketle, hekim folklorundaki stereotipler ve bu stereotiplere bağlı olarak yapılan şakaların ele alındığı bir yazı (Büyükokutan Töret, 2018: 13-30) ile hekimlik mesleğindeki normlar üzerine değerlendirmelerin yapıldığı bir makale de tarafımızca yazılmıştır (Büyükokutan Töret, 2020: 153-184). Beyaz Önlük Giyme ritüeli ile uzak ilişkili olsa da hasta ve yakınlarının, hekimlerin beyaz önlük giymesi konusundaki tutum ve davranışlarını ortaya koyan bir makale de bulunmaktadır (Sönmez, 2010: 1-6).

\section{Beyaz önlük giyme töreninin ortaya çıkış süreci}

Meslekten olmayan bir kişinin sağlık mesleğinin bir üyesine “dönüşümünü” sembolize eden Beyaz Önlük Töreni (White Coat Ceremony) ilk kez Chicago Üniversitesi Pritzker Tip Fakültesi'nde 1989 yılında ortaya çıkmıştır. Törenin çıkış nedeni, şort ve beysbol şapkasıyla hastaların da bulunduğu fakülteye gelen öğrencilerden rahatsız olan bir öğretim üyesinin şikâyetidir. Bu durum karşısında, okul yönetiminin yanı sıra öğrencilerin ailelerinin de davet edilerek öğrencilere hekim önlüğü verilen bir toplantı düzenlenmiştir. Bu toplantıda öğrencilere, fakültede hastalar da bulunduğu için profesyoneller gibi görünmeleri, beyaz önlük giymeleri ve rollerine uygun şekilde davranmaları istendiği belirtilmiş ve böylece beyaz önlük töreninin temeli atılmıştır (Warren, 1999).

İlk tam teşekküllü Beyaz Önlük Töreni, 1993 yılında Columbia Üniversitesi Doktorlar ve Cerrahlar Koleji'nde gerçekleşmiştir. Her yıl gerçekleşen bir tören hâline gelmesinde Arnold P. Gold Vakfı'nın girişimleri önemlidir. Colombia Üniversitesi öğretim üyelerinden Arnold P. Gold öncülüğünde kurulan vakıf, eğitimin ilk gününden itibaren şefkatli, iş birliğine dayalı, bilimsel olarak mükemmel hekimlerin yetişmesini sağlamayı amaçlamaktadır. Arnold P. Gold, tıp eğitimlerinin sonunda öğrencilerin Hipokrat Yemini’ni etmelerine yönelik mevcut uygulamanın geç gerçekleştiğini ifade etmiştir (URL-1). Zaten Hipokrat da yemini eğitimin sonunda değil tıp öğretiminin başında etmiştir (Reiser ve Ribble, 1995: 857). Bunun üzerine Gold Vakfı, tıp eğitiminin en başında tıpta hümanizmi vurgulamanın bir yolu olarak Beyaz Önlük Töreni'ni başlatmıştır (URL-1). Tören, meslek için psikolojik, entelektüel ve etik bir sözleşme yaratması ve tıp eğitiminin en başından itibaren tıp pratiğinde empatiyi teşvik etmesi bakımından işlevseldir (URL-2).

Beyaz Önlük Töreni Columbia'nın çok ötesine geçmiş, birkaç yıl içinde Kuzey Amerika'daki çoğu tıp fakültesi tarafından kabul edilmiştir. Bugün, Amerika Birleşik Devletleri’ndeki $\mathrm{AAMC}^{4}$ onaylı tıp okullarının yüzde doksan dokuzunda, hemşirelik, eczacılık, diş hekimliği gibi sağlık eğitimi veren diğer fakülteler tarafindan da Beyaz Önlük Töreni ya da benzer bir ritüel gerçekleştirilmektedir (URL-1). Amerika Birleşik Devletleri dışındaki tıp okulları ve diğer sağlık okullarında da düzenlenmeye başlanmıştır (URL-4). Bu bağlamda, Ankara ili özelinde hekimlerle yapılan görüşmelerden hareketle Karataş'ın da (2017: 185) belirttiği üzere, Beyaz Önlük Töreni, Eric Hobsbawm'ın (2006: 1-18) icat edilmiş geleneğin özelliklerine sahiptir. ${ }^{5}$ 
Türkiye'de bu tören ilk kez 2000 yılında Hacettepe Üniversitesi Tıp Fakültesi’nde dönemin Dekanı Prof. Dr. İskender Sayek' in öncülüğünde planlanmış ve düzenlenmiştir (Karataş, 2017: 186). Prof. Dr. Erdem Aydın'ın katkısı, tıp öğrencilerinin yemin ederek başlaması fik ri ve yemin metninin hazırlanması şeklinde olmuştur. Aydın, öğrencilerin başta stajerlik ve intörnlük dönemleri olmak üzere eğitimleri boyunca hastalar ile iletişim kurmaları, mahremiyet, gizlilik, tıbbi araştırmalar gibi konularda bir hekim kadar etik dünyanın içerisinde bulunmaları nedeniyle tıp öğrencilerinin sadece mezuniyetlerinde değil fakülteye başlarken de yemin etmeleri gerektiğini düşünmüştür. Dekanlık, Beyaz Önlük Giyme Töreni kapsamında topluca yemin metnini okutma uygulamasını 2000 yılında, ders yılı başında başlatmıştır. Kısa sürede birçok üniversitenin tıp fakültelerinin yanı sıra simgesi beyaz önlük olan eczacılık, diş hekimliği, veterinerlik ve sağlık bilimleri fakültelerinde de düzenlenmeye başlanmıştır. ${ }^{6}$

Beyaz Önlük Giyme Töreni’nin düzenlendiği üniversitelerden biri de Eskişehir Osmangazi Üniversitesi'dir. Tören Eskişehir Osmangazi Üniversitesi Tıp Fakültesi’nde ilk kez 2002-2003 öğretim yılında düzenlenmiştir. O dönemde dekan yardımcısı olan Prof. Dr. Kevser Erol törenle ilgili şu açıklamayı yapmıştır: Beyaz Önlük Giyme Töreni daha önce fakültemizde yoktu. Türkiye'de de pek yaygın değildi ama bizden sonra birçok tıp fakültesinde uygulanmaya başladı. Hatta bize de ilk öneren Fizyoloji Anabilim Dalı öğretim üyesi Prof. Dr. Kubilay Uzuner olmuştur. Amerika'da her yıl uygulanan bir törenmiş. Dönemin dekanı da sıcak bakınca onları örnek alarak başlatmıştık. Birinci sınıf öğrencilerini mesleğe 1sıtmak adına iyi bir başlangıç oldu. Çünkü tıp fakültesini kazanan öğrenciler liseden mezun olup geldikleri için önce biraz tedirgin duruyorlar ama beyaz önlüğü giydikten sonra özgüven kazanıyorlar. Bu onların da hoşuna gidiyor. Mesleğe daha kolay adaptasyonlarını sağlıyor”.

\section{Yapısal özellikleriyle beyaz önlük giyme töreni}

Eskişehir Osmangazi Üniversitesi Tıp Fakültesi’nde Beyaz Önlük Giyme ismiyle anılan bu tören, 2002-2003 öğretim yılından bugüne uygulanmaktadır. Tıp fakültesine yeni kaydolmuş, birinci sınıfa başlayacak öğrencilerin mesleğe girişlerini temsil eden bu geçiş ritinin ana temasını, "Hekim adaylarına, saygın bir mesleğe, uzun ve zor bir eğitim sürecine, meslek hayatına, ciddi bir göreve, sorumluluğa ve yeni kimliklerinin ilk gününe hoş geldiniz demek" $(\mathrm{KK}-1)^{7}$ cümlesi oldukça güzel ifade etmektedir. Önceden ders arasında gerçekleştirildiği ve öğrencilerin ön hazırlığı olmadığı belirtilen tören, son iki yıldır “1. Sınıf Öğrencileri İlk Hafta Etkinlikleri” kapsamında düzenlenmektedir. Pandemi nedeniyle tören en son 2018-2019 öğretim yılında, 10-14 Eylül 2018 tarihleri arasındaki etkinliklerin beşinci gününde Eskişehir Osmangazi Üniversitesi Kongre ve Kültür Merkezi'nde yapılmıştır. 2018-2019 Öğretim Yı1ı 1. Sınıf Öğrencileri İlk Hafta Etkinlikleri’ne bakıldığında, öğrencileri söz konusu törene hazırlama niteliğinde, ilk olarak dönemin fakülte dekanı Prof. Dr. Ali Arslantaş, "Açılış Dersi”" adı altında öğrencilere tıp fakültesi öğrencisi olmanın anlamını ve kurumun tarihini içeren bir konuşma yapmıştır. Ardından dönemin dekan yardımcısı Prof. Dr. Aysel Akalın, fakülteyi ve üniversiteyi tanıtmıştır. Programın ikinci gününde öğrenciler, fakültenin mezunlarıyla buluşturulmuştur. Fakültenin ilk mezunlarından olan emekli öğretim üyeleri ile öğrencilere 
rol model olabilecek hekimler öğrencilerle bir araya getirilmiştir. Dönemin başhekimi Başar Sırmagül üniversite hastanesinin tanıtımını yapmıştır. Programın üçüncü gününde öğrenciler, uzmanlarla bir araya getirilmiştir. İş güvenliği uzmanı tarafından temel iş sağlığı ve güvenliği eğitimi ilk üç gün boyunca belli saatler aralığında verilmiştir. Dördüncü gün Koç Üniversitesi dekan yardımcısı Prof. Dr. İhsan Solaroğlu ile söyleşi gerçekleştirilmiştir. Söyleşinin ardından öğrenciler organizasyonun gerçekleştirileceği mekâna götürülerek Beyaz Önlük Giyme Töreni provası yapılmıştır. Asıl tören, etkinliklerin son gününde saat 10.00' da gerçekleştirilmiştir.

Törenin amac1, öğrencilere liseden sonra tıp fakültesine geldiklerini hissettirmek ve hekimliğin nasıl bir meslek olduğunu, bu süreçte nelerle karşılaşacaklarını, neleri kabul ederek bu işe başlayacaklarını, hekim olmanın sorumluluklarını anlatmaktır. Beyaz önlüğün giyilmesiyle birlikte öğrenciler mesleğe girdiklerinin bilincine varmaktadır (KK-5). Tören, tıp fakültesini kazanan öğrencilere, hekimlik mesleğinin usta-çırak ilişkisi olduğunu daha birinci sınıftan göstermektedir. Bir araba ustasının çırağı nasıl ilk kez arabayla ilgilenirken bir tulum giyiyor ve o tulumla "Sen artık bizimlesin, bu işin bir parçasısın” mesajı veriliyorsa, Beyaz Önlük Giyme Töreni de aynıdır (KK-2). Törende beyaz önlük giymiş olan sözlü kaynaklar, doktorluğa adım atmış gibi hissettiklerini (KK-4, KK-5, KK-10), sorumluluk yüklendiklerini (KK-8), gururlandıklarını (KK-4, KK-9), motive olduklarını (KK-7), duygusal anlar yaşadıklarını (KK-10) ve çok heyecanlandıklarını (KK-9) ifade etmişlerdir.

Törene öğrencilerin yanı sıra aile ve yakınları, Eskişehir Osmangazi Üniversitesi Tıp Fakültesi öğretim üyeleri, dekan, rektör, vali, il emniyet müdürü, sağlık müdürü, yargıtay üyesi ve diğer protokol üyeleri de katılmaktadır. Beyaz Önlük Giyme Töreni, “Aziz Atatürk, dava arkadaşları, Türk tıbbına ömürlerini adayan bugün aramızda olmayan hekimlerimiz ve Eskişehir Osmangazi Üniversiteli hekimlerimizin aziz hatırası" adına saygı duruşu ve İstiklal Marşının okunmasıyla başlamaktadır. Törenin başrolünde tıp fakültesi dekanı bulunmaktadır. Hem öğrencileri karşılamak hem de mesleğin sorumluluklarını belirtmek adına bir konuşma yapmaktadır. Öğrencilere liseden sonra tıp fakültesine geldiklerini hissettiren bu konuşmada, hekimliğin simgesi olan beyaz önlüğün temsil ettiği anlamlar üzerinde durulmaktadır (KK-3). Eskişehir Osmangazi Üniversitesi 2018-2019 öğretim yılında düzenlenen törende Tıp Fakültesi Dekanı Prof. Dr. Ali Arslantaş, beyaz önlüğün ne anlam taşıdığını şöyle anlatmıştır: "Hekimlik mesleğinin simgesi olarak giydiğiniz bu önlük sadece iki metrelik beyaz bir kumaş değildir. Bu önlügün anlamını çok iyi bilmek gerekir. Beyaz önlük saflıktı, temizliktir, güçtür, kudrettir, sorumluluktur, vebaldir. Üzerindeki lekeler, kanlar, kırışıklıklar çalışkanlıktır, gururdur, kutsallığgn nişanesidir. Önündeki düğmeler zorluktur, özveridir. O nedenle zor kapanır. Eğitimdir, öğretimdir ve zorlu yolların parke taşıdır. Tecrübedir, bilgeliktir, deneyimdir. En kutsal anlamı ise hastalarının duası, yakınların minnettarlığıdır. O düğmeler sizleri kazalardan, belalardan korur. O düğmeler aynı zamanda ananızın, babanızın yüzündeki parıltıdır, gururdur, sevinçtir”.

Yapılan konuşmalarla, öğrencilerin Türkiye’nin nadide öğrencileri oldukları, kazandıkları fakültenin saygın bir kurum olduğu, fakültenin tarihsel gelişimi belirtilmekte, mesleğin her dönemde zor olduğu, öğrencilerden çok çalışmaları, sabırlı olmaları, hocalarını iyi dinlemeleri, hekim olmaya uygun davranışlar sergilemeleri beklendiği ifade edilmektedir. Hekim- 
lik sanatını öğrenmeye adım atılan bu ilk günün Beyaz Önlük Giyme Töreni ile başlayacağı ve tüm katılımcıların buna şahit olacağı belirtilmektedir. Yaşanan olaylardan etkileyici örneklerle hekimlerin ne kadar hayata dokundukları ve bunun karşılığının para ile ölçülemeyeceği vurgulanmaktadır. 2018-2019 öğretim yılında düzenlenen törende rektörün vermiş olduğu bir örnek şöyledir: "İskoçya'da Fleming adında fakir bir çiftçi yaşar. Bir gün tarlada çalışırken bir çığlık duyar. Sesin geldiği yere koşar. Beline kadar bataklığa batmış bir çocuğun kurtulmak için çırpınıp durduğunu görür. Çiftçi çocuğu bataklıktan çıkarır ve ölümden kurtarır. Ertesi gün Fleming'in evine şık giyimli bir aristokrat gelir. Çiftçinin kurtardığ çocuğun babası olduğunu ve bunun karşılığını vermek istediğini söyler. Yoksul ve onurlu Fleming ödülü geri çevirir. Tam bu sırada kapıdan çiftçinin küçük oğlu görünür. Aristokrat, çocuğu kendisine verirse ve iyi bir eğitim almasını sağlayacağını söyler. Fleming'in oğlu aristokratın desteğinde eğitim görür. Çiftçi Fleming'in oğlu Londra'daki bir Tıp Fakültesi'nden mezun olur ve tüm dünyaya adını penisilini bulan Sir Alexander Fleming olarak duyurur. Bir süre sonra aristokratın oğlu zatürreye yakalanır ve onu penisilin kurtarır” (KK-6).

Törende yapılan konuşmalarda, öğrencilerin aile ve yakınlarına da hitap edilmektedir. Gerek dekan gerekse rektör tarafından, ailelere teşekkür etmek ve mesleğe dair farkındalık oluşturmak adına onlara yönelik konuşmalar yapılmaktadır (KK-3). Dönemin fakülte dekanı Prof. Dr. Ali Arslantaş'ın şu cümlelerindeki gibi ifadelerle ailelere emek, gayret ve desteklerinden dolayı teşekkür edilmektedir. "Siz değerli anneler, babalar. Çocuklarınızla ne kadar gururlansanız azdır. Belki de ilkokuldan beri evlatlarınızın en iyi eğitimi alması için didinip durdunuz. En iyi okullara, en iyi hocalara ulaşmaya çalıştınız. Tüm zorlu hayat koşullarına rağmen bu kutsal mesleğin birer elemanı olması için her türlü fedakârlığı yaptınız. Belki de yemediniz yedirdiniz, giymediniz giydirdiniz ve belki de siz okuyamadınız ama okuttunuz. Hem de nasıl okuttunuz. Siz yapılması en zor olanı başardınız. Sizler artık hekim adaylarının annesisiniz, babasısınız. Sizler ileride Doktor Nilgün Hanım'ın ya da Doktor Engin Bey’in annesi, babası olarak bilinecek ve o mutluluğu, onuru tadacaksınız. Bu pırıl pırıl evlatlarımız çocukluk çağından beri ‘büyüyünce ne olacaksın?' sorusuna cevap olarak çoğunlukla 'doktor olacağım' dediler belki de. Bu yoldaki en büyük adımı bugün atıyorlar. Evlatlarınız bize emanet".

Törene katılan öğretim üyelerine de ileride meslektaşları olacak olan öğrencilerle aynı düzlemde birleşmeleri, grup hissi ve kimliği ile hareket etmelerine yönelik konuşmalar yapılmaktadır. Eskişehir Osmangazi Üniversitesi Tıp Fakültesi 2016-2017 yılındaki törende, dönemin Tıp Fakültesi Dekan Vekili Prof. Dr. Alparslan Birdane’nin öğretim üyelerine mesajı şöyledir: "Fakültemizin değerli öğretim üyeleri, kıymetli hocalarım. Ülkemizin aydınlık yarınlara ulaşması toplumun tüm kesimlerinin üzerine düşeni hakkıyla yerine getirmesiyle mümkün olacaktır. Bizler şimdiye kadar bu fakülteden nice mezunlar verdik. Bugün yeni öğrencilerimizle yepyeni bir başlangıç yapmaya hazır bulunuyoruz. Daha fazlasını, daha iyisini yapmak için el birliğiyle gayret göstereceğiz. Onlar için rol model hocalar, akademisyenler, hekimler olacağız. Talebelerimizi bizim evvelce yaşamış olduğumuz uzun ve zor süreç bekliyor. Onların geleceklerinde pay sahibi olacağız. Bu büyük bir şeref ama aynı zamanda ciddi bir sorumluluktur. Şimdiden ellerinize ve emeklerinize sağlık. Hepinize kolaylıklar diliyorum". 
Konuşmaların ardından, törene katılan öğretim üyesi sayısına göre öğrenciler bölünmektedir. Her bir öğretim üyesi belirli sayıdaki gruplardan oluşmuş öğrencilere beyaz önlüklerini giydirmektedir. İlk sırada davet edilen öğrenci, fakülteye en yüksek puanla girendir ve puan sırasına göre devam edilmektedir. Üniversiteye dereceyle giren öğrencilere önlükleri rektör ve rektör yardımcısı tarafından giydirilmektedir. Ancak burada önlük giydirecek olan kişilerin, tıp mesleğinden olması şartı bulunmaktadır. Protokol sırasına uygun olarak gidilmekle birlikte hekim değilse öğrencilere önlük giydirememektedir. Dereceye giren öğrencilerden sonra diğerler öğrenciler ve akademik sıraya göre öğretim üyeleri anons edilip heyecanı arttırıcı müzikler eşliğinde sahneye davet edilmektedir. Öğretim üyeleri, kendi grubundaki öğrencileri tebrik edip beyaz önlüklerini giydirdikten sonra rulo şekline getirilmiş olan hekimlik andını verir. Gruplar hâlinde fotoğraf çektirilir (KK-3).

Kongre ve Kültür Merkezinin tören salonunda protokol ve öğretim üyelerinin hemen ardındaki koltuklarda öğrenciler, en arkada da aile ve yakınlar oturmaktadır. Öğretim üyeleri ve fakülte yöneticileri beyaz önlükleri ile katılırken öğrenciler törene önlüksüz gelmektedir. Daha önce üzerlerine göre dikilen önlükler öğrencilerin ellerinde bulunmaktadır (KK-2). Tüm öğrenciler önlüklerini giydikten sonra hep bir ağızdan Hipokrat yeminini andıran bir and okunmaktadır. Eskişehir Osmangazi Üniversitesi'nde "Hekimlik Andı" olarak adlandıran metin şöyledir: "Hekimlik mesleği üyeleri arasına katıldığım şu anda kendimi insanlık hizmetine adayacağıma söz veriyorum. Hocalarıma karşı duyduğum ve gösterdiğim saygıyı hayatım boyunca koruyacağım. Meslektaşlarımı kardeş olarak görecek, ilişkilerimde deontoloji kurallarına bağlı kalacağım. Sanatımı vicdanıma uyarak doğruluk ve gururla uygulayacağım. Hastamın sağlığı baş kaygım olacak, hastalarımın sırlarını başkalarına söylemeyeceğim. Hekimlik mesleğinin şerefini ve yüce geleneklerini sürdüreceğim. Din, milliyet, 1rk, parti ve sosyal sınıf kaygılarının mesleğim ile hastam arasına girmelerine yer vermeyeceğim. İnsan hayatına ana karnına düştüğü andan sonuna kadar mutlak bir saygı duyacağım. Baskı altında bile olsam tıp bilgilerimi insanlık yasaları dışında kullanmayı kabul etmeyeceğim. Kimsenin etkisi ve baskısı altında kalmadan tüm bunları yerine getireceğime namusum ve vicdanım üzerine and içerim".

Hekimlik andının okunmasının ardından kongre ve kültür merkezinin önündeki toplu fotoğraf çekimleriyle tören sona erer. Öğrenciler, mezun oldukları liseden törene katılan arkadaşları, okul müdürleri ve öğretmenleri ile ayrıca fotoğraf çektirirler. Lise arkadaşlarının arasından Eskişehir Osmangazi Üniversitesi Tıp Fakültesi’ni kazananlar varsa bir araya gelinip mezun olunan lisenin isminin yazılı olduğu pankart açılarak pozlar verilir. Okul yöneticileri ve öğretmenleri tıp fakültesi öğrencilerini tebrik eder, kendileriyle gurur duyduklarını söylerler (KK-13).

Tören sonunda öğretim üyeleri ve aileler için kokteyl olmaktadır. Öğretim üyeleriyle ailelerin tanışıp sohbet edebildiği bu kokteyllerde ilk başlarda yöresel çi börek ikram edildiği ancak masraflı olduğu için bugün daha basit tatlı ve tuzlu kurabiyelerin ikram edildiği belirtilmiştir (KK-3). Son yıllarda bir organizasyon şirketiyle anlaşılmış, salonun tasarımı, düzeni, müzik sistemi ve tören sonundaki kokteyl şirket tarafından yapılmaya başlanmıştır $(\mathrm{KK}-2)$. 


\section{5. İşlevsel özellikleriyle beyaz önlük giyme töreni}

Tıp fakültesine yeni başlayan öğrencileri, mesleğin simgesi olan beyaz önlük altına alarak mesleğe kabul etme temel işlevine sahip olan Beyaz Önlük Giyme Töreni; öğretim üyeleriyle öğrencileri bir araya getirmek, hekimliğin görev ve sorumluluklarını belirtmek/hatırlatmak, tıbbın etik yönünün de bulunduğunu vurgulamak işlevleriyle bugün Türkiye'deki üniversiteler tarafından da düzenlenmektedir. Beyaz Önlük Giyme Töreni’nin işlevsel boyutu hakkındaki değerlendirmeleri, törenin bugün uygulanan şeklini alması ve her yıl gerçekleştirilen bir tören hâline gelmesinde önemli katkısı olan Arnold P. Gold Vakfi'nın tespitleri üzerinden yapmakta fayda vardır.

Arnold P. Gold Vakfı töreni oluşturan altı temel bileşenden söz etmektedir. Söz konusu altı bileşenin birincisi, öğrencilerin en yakını olan ve onlara olan desteği temsil eden ailelerin ve arkadaşların törene katılmaya davet edilmesidir (Gillon, 2000: 84). Törene katılan aileler, evlatlarının beyaz önlük giyerek hekim kimliğine sahip olma anına tanıklık etmektedir ki aileler üzerinde büyük bir etkiye sahiptir. Türk toplumunda ailenin bir çocuğu tıp fakültesini kazanmışsa aile kendini güvende hisseder. Çocuğu hekim olacaktır. İleride bir sağlık sorunuyla karşılaştığında en yakınından destek görecektir. Bu açıdan Türk ailesi için çok önemli bir başlangıçtır. Aileler de bu gururu yaşamak istedikleri için törene hevesle katılmaktadır (KK-3). Sözlü kaynaklar, tıp fakültesinin çoğu kişinin isteyerek geldiği bir bölüm olması, hekimliğin her dönemde önemini koruyacak bir meslek grubu olması nedeniyle ailelerin de törende çok mutlu olduklarını kendileriyle gurur duyduklarını belirtmişlerdir (KK-4, KK-6, KK-14). Türkiye'deki tıp ve mühendislik bölümlerine ailelerin yaklaşımının daha farklı olduğunu ifade eden bir hekim, törende annesinin de gözlerinin yaşardığını, "Oğlum beyaz önlük giydi, doktor oldu, yemin etti” diye övündüğünü, kendisinin olmadığı ortamlarda da sürekli töreni anlattığını belirtmiştir (KK-5). Görevi nedeniyle izin alıp gelemeyen anne ve babalar bu anı kaçırdıkları için çok üzgün olduklarını ancak çocuklarının beyaz önlük giyerken çekilen fotoğraflarına bakıp, videolarını izleyerek onlarla gurur duyduklarını anlatmışlardır (KK-15). Yapılan konuşmalarda ailelere yönelik olumlu göndermelerin yanı sıra beyaz önlüklerini giyen öğrenciler alkışlandıktan sonra çocuklarına sürekli destek olan, onlar için her türlü fedakârlıkta bulunan ailelerin de ayakta alkışlanması motivasyonu arttırmaktadır. Bu açıdan bakıldığında tören, hem öğrencilerin hem de ailelerin onur duyması, uzun ve zorlu bir sınav hazırlığının ardından elde edilen mesleki kimlikle psikolojik olarak rahatlamayı sağlaması açısından işlevseldir.

Töreni oluşturan bileşenlerin ikincisi, girmek üzere oldukları yeni mesleğin ve okulun değerler sistemini temsil eden dekanlar, tıp fakültesi öğretim üyeleri ve hastanenin diğer kıdemli hekimleri tarafından yapılan öğrencileri karşılama törenidir (Gillon, 2000: 84). Öğrencilere "Kulübe hoş geldin" demek için yapılan bu mesleki karşılama töreni ile onlara "Biz bir aileyiz ve sizlerle gurur duyuyoruz" mesajı verilmektedir. Meslek hayatları boyunca halkın hizmetinde olacakları için halka iç içe olmaları, kendilerini halktan üstün görmemeleri belirtilmektedir (KK-2). Her şeyin paraya döküldüğü ve hafife alındığı bugünlerde insana insanca davranılabilmesi adına hekimliğin ne kadar önemli olduğu hissettirilmeye çalışılmaktadır (KK-11). Bu karşılama, mesleğe yeni katılmış bir çırağa tulum giydirmeye benzetilmektedir (KK-2). Törenle birlikte hekimliğe iyice adım attığını hissetmek öğrencileri 
motive etmektedir. Kendini bu dünyaya aitmiş gibi hissetmeye başlayan öğrencilerin çalışma şevkleri artmaktadır (KK-5). Törende belli bir tarihi geçmişe atıf yapılarak, tıbbın insanlığa hizmet esasına dayandığının vurgulanması öğrencileri meslek kültürüne bağlarken ailelere de mesleğin değerlerini aktarmaktadır. Fakültenin ilk mezunlarından olan emekli bir öğretim üyesinin, şu an kendisi de aynı tıp fakültesinde öğretim üyesi olan kızının yaptığı konuşma sözlü kaynağın annesini çok etkilemiştir. Öğretim üyesinin kızı Eskişehir Osmangazi Üniversitesi Tıp Fakültesi'nde öğrenciyken babasına, fakültede kadavralarının olmadığını söyleyince babası gönüllü olarak kadavra olmak istemiştir. Vefatının ardından kızı onu fakülteye kadavra olarak bağışlamıştır (KK-14)

Üçüncüsü, rol model bir hekim tarafindan yapılan ilham verici bir derstir (Gillon, 2000: 84). Birinci sınıf öğrencileri ilk hafta etkinliklerinin tıp fakültesi dekanı tarafından yapılan açılış dersi ile başlaması öğrencilere tıp etiğinin tanımı, gerekçesi ve tıp etiği ilkelerinin aktarılması, mesleki uğraşı insan olacak olan hekim adaylarının bilinçlendirilmesi açısından işlevseldir. Bunun yanı sıra program süresinde gerek fakülteden mezun olup emekli olan öğretim üyeleri gerek çalışan uzmanlar gerekse diğer üniversitelerden davetli bilimsel anlamda tanınan öğretim üyeleri ile bir araya gelen öğrenciler tecrübi bilgileri öğrenme ve meslektaşlarıyla vakit geçirme imkânı elde etmektedir. Hocalarının öğütleri ve anılarıyla mesleğe başlangıç yapan öğrenciler, girmiş oldukları mesleğin ciddiyetini, sorumluluğunu ve vicdanını hissetmekte (KK-16), yapacakları hataların insana etki edeceğini, verdikleri kararların insan hayatına mal olacağını öğrenmiş olmaktadır (KK-12).

Dördüncüsü, kişisel olarak teslim edilen bir inanç ve güven hediyesi olarak kıdemli hekimler tarafından öğrencilere beyaz önlüğün giydirilmesidir. Önlük giydirme kıdemli hekimlerin, öğrencilerin hekim olma geleneğini sürdürme becerisine olan inancını gösterdiği bir “bağlanma sürecinin” parçasıdır (Gillon, 2000: 84). Eskişehir Osmangazi Üniversitesi'nde başta dekan olmak üzere öğretim üyelerinin de törene beyaz önlükle katılmaları, sadece yönetici ve öğretim üyesi olarak değil hekim olarak törende bulunulduğunu simgelemektedir. Açılış konuşmalarının ardından öğrencilere de giydirilen beyaz önlükle salon tek renk olmaktadır. Beyaz önlüklerini giyen öğrenciler bir taraftan beyaz önlüklüler grubuna dâhil olurken diğer taraftan geleneği de devralmaktadır. Öyle ki öğrenciler geleneğin sürekliliği taraftarıdır. Stresli ve yoğun bir dönemi geride bırakıp geldikleri için bu törenin kendilerini rahatlattığını ve son zamanlarda karşılaşılan hekimlere darp, şiddet olaylarına karşı gerçekten değerli bir iş yaptıklarını ve bir şekilde karşılığını alacaklarını hissettirdiğini, geleceğe umutla bakmalarını sağladığını ifade etmişlerdir (KK-8, KK-9). Hocalarının elinden önlük giymek öğrenciler için törenin en etkileyici ve motive edici yönüdür. Öğrenciler, kendilerine önlük giydiren öğretim üyesinin uzmanlık alanıyla, ileride kendilerinin eğitim alacağı uzmanlık alanı arasında tahmin yürütmeye çalışmaktadır (KK-7). Henüz tıp eğitiminin başındayken hocalarının kendilerine önlük giydirip tebrik etmeleri, doktor diye hitap etmeleri öğrencilerin hekimliği benimsemeleri ve bağlanmaları açısından işlevseldir.

Beşinci bileşen, Hipokrat yemini veya diğer benzer yeminlerin öğrencinin akranları, ailesi, arkadaşları ve hocaları nezdinde okumasıdır. Bu yemin öğrencilerin, önemli tanıkları önünde mesleki yükümlülüklerini ve sorumluluklarını üstlenmeye istekli olduklarının kamu- 
oyu tarafından kabulüdür (Gillon, 2000: 84). Törenin önemli bir parçası olan mesleki yemin hakkında Amerika' da olumsuz eleştiriler de yapılmıştır (Veatch, 2002: 5). Eskişehir Osmangazi Üniversitesi'nde okunan Hekimlik andının içeriğine bakıldığında, bilimsel yöntemlerin ışığında tıp mesleğinin icra edilmesi, hasta mahremiyetine önem verilmesi, insan sağlığının her şeyin üzerinde tutulması, meslektaşlarla iyi ilişkiler kurulması ve hocalara saygı gösterilmesi konularına değinildiği görülmektedir. Kimsenin etkisi ve baskısı altında kalmadan öncelikle iyi bir tıp öğrencisi olmak için söz verilmektedir. Hipokrat andına benzeyen birleştirici cümlelerden ibaret olan metnin hep bir ağıdan okunması öğrencileri tıp mesleğine geçiren bir işaret gibi olmaktadır (KK-4). Yeminin hep birlikte ediliyor olması hem arkadaşlık hem ekip ilişkisini, ruhunu canlandırması açısından işlevseldir (KK-8). Bunun yanı sıra yemin öğrencilerin mesleğin hâli hazırdaki icracıları olan hekimlerle aynı mesleki değerlere bağlanmalarını sağlamaktadır (KK-16).

Altıncı bileşen, geçiş ritlerinin ardından öğrencilerin yeni mesleki statülerini kutlayan kabul törenidir. Önemli ve unutulmaz bir anı güçlendirmede yemek ve parti atmosferi etkili bir unsurdur (Gillon, 2000: 84). Törenden sonra fakülte dekanlığı tarafından organize edilen kokteylde sunulan ikramlar öğretim üyelerini, öğrencileri ve aileleri bir araya getirmesi, kaynaştırması açısından işlevseldir (KK-17). Aynı amaç için bir araya gelen bireyleri aynı çatı altında toplayan bu organizasyonlar, öğretim üyeleri ile öğrencilerin ilk iletişimlerine vesile olurken özellikle aynı şehirde yaşayan aileler birbirleriyle anlaşıp arkadaş, dost çevrelerini genişletebilmektedir.

Eskişehir Osmangazi Üniversitesi'nde gerçekleştirilen Beyaz Önlük Giyme Töreni’nde, Arnold P. Gold Vakfı'nın belirtmiş olduğu altı bileşenin işlevlerinin dikkate alındığı ve törenin aynı sıralamayla yapıldığı tespit edilmiştir. Öğrencilere bilimi rehber edinerek çok çalışmaları ve tıp öğreniminin başından itibaren mesleğin icracılarının tecrübe ve deneyimlerinden istifade etmeleri gerektiğini vurgulayan bu süreç, katılımcılara hekimlik mesleğinin değerlerin aktarılması/hatırlatılması açısından da işlevseldir.

\section{Sonuç}

Beyaz Önlük Giyme Töreni, tıp eğitimine kayıt yaptırmış öğrencileri karşılayan, onların tıp camiasına girişlerini kutlayan, kendilerine hekim kimliği atfeden ve ilk günden itibaren bu mesleki kimliğin benimsenmesini ve sorumluluklarının farkına varılmasını amaçlayan bir geçiş ritidir. Usta değil de çırak olarak hekimlik mesleğine kabul törenidir. Törende mesleği usta olarak icra eden kişiler tarafından beyaz önlüğün öğrencilere giydirilmesi söz konusu kabulün ilk göstergesidir. Beyaz önlüğün temsil ettiği anlamlar ve hekimliğin kutsallığ üzerine yapılan konuşmalarla çırak, dâhil olduğu meslek grubunun ve sorumluluklarının farkına vardırılmaya çalışılmaktadır. Tıp fakültesi boyunca devam edecek olan bu süreçte, fakülte yöneticileri ve öğretim üyeleri olarak öğrencilerin yanında olunacağına dair mesaj da söz konusu kişilerin törene beyaz önlükle katılmasıyla verilmektedir. Bizzat mesleğin ustaları tarafından giydirilen beyaz önlüklerle öğrenciler, çırak olarak da olsa, meslektaşlarının arasına kabul edilmiş olurlar. İçeriği her kurum tarafından değiştirilebilen hekimlik andının 
okunması da mesleğe kabulün diğer bir göstergesidir. Hipokrat'ın yaptığı gibi tıp eğitimin en başında okunan bu and, öğrencilerin tıbbın etik değerlerini ustalarının ve tüm katılımcıların huzurunda kabul ettiklerinin bir göstergesidir.

Hekimlik mesleğine ilk geçiş riti olan törenin geçmişi çok eskiye dayanmamakla birlikte eskiden beri yapılageldiğine yönelik bir izlenim uyandırmaktadır. Öyle ki son iki yıl içerisinde beyaz önlük törenine katılmış olan hekim adayları ve aileleri beyaz önlük töreninin çok eski bir ritüel olduğunu düşündüklerini belirtmişlerdir. 2000 y1lından önce mezun olan bazı öğretim üyeleri de kendi zamanlarında olup olmadığını hatırlayamamış, olmuşsa da katılmadıklarını/katılamadıklarını ifade etmişlerdir. Birinci sınıf öğrencilerinin ilk hafta etkinlikleri programındaki uzmanlarla/öğretim üyeleriyle buluşma ve söyleşilerde, törenin her yıl düzenlendiğine vurgu yapılması katılımcılara, hekimlikte Beyaz Önlük Giyme Töreni’nin başlangıçtan beri var olduğunu düşündürmektedir.

Törenin işleyiş şekli ve törende okunan hekimlik andı ile ilgili olarak sözlü kaynaklar olumlu görüş bildirmiştir. Eskişehir Osmangazi Üniversitesi'ndeki beyaz önlük töreninde okunan hekimlik andının içeriği hem öğretim üyeleri hem de öğrenciler tarafından evrensel değerler olarak kabul edilmektedir. Hekimliğin gereklerini anlatan bir metin olması, içinde rahatsız edici bir cümlenin bulunmaması ve gelenek hâline gelmiş olması nedeniyle kimsenin değiştirmeyi düşünmeyeceği bir yazı olduğu belirtilmektedir. Okunan metnin farklı din, dil ve milletten olanlar arasında bir ayrım gözetmediği, öğrencilere yolun en başında kendilerini gerçekten hekim gibi hissettirebilmek adına okutulduğu ifade edilmektedir.

“Aramıza hoş geldin töreni” olarak tanımlanan/algılanan törenin, motive etmek heveslendirmek, sorumluluk yüklemek işlevlerinin yanı sıra mesleğe atılan ilk adıma dair hoş bir anı olarak hafizalarda yer etmesi nedeniyle devam etmesi istenmektedir. Hatta mesleğe kabul durumunu daha da vurgulamak için beyaz önlük giydirildikten sonra bir de stetoskop takılması düşünülmüş ancak ekonomik sıkıntılardan dolayı temin edilememiştir. Törenin sürekliliği adına, organizasyonun kongre ve kültür merkezine taşınması, kokteyl düzenini ve müzik sistemini daha profesyonel olarak yapan bir organizasyon şirketiyle anlaşılması önemlidir. Hatta pandemiden sonraki süreçte üniversitenin Halkbilim Uygulama ve Araştırma Merkezi’nden destek alınarak canlı müzik de yapılabileceği ve panayır gibi bir ortamın oluşturulabileceği düşünülmektedir. Türkiye'deki pek çok üniversitenin sağlık bilimleri, diş hekimliği, eczacılık, veterinerlik gibi sağlık eğitimi veren fakülteleri tarafında da düzenlenir hâle gelmiş olması törenin gelenekselleşmeye doğru gittiğinin göstergesidir.

\section{Notlar}

1 Ritüel ve rit terimleriyle ilgili yapılan tanımlar için bk. (Özbudun, 1997: 17; Rappaport, 2003: 396-397; Eriksen, 2009: 95-97; Goody, 2018: 23-49; Çilingir Cesur, 2020: 21-28).

2 Batıdaki ve Türkiye'deki meslek folkloru araştırmalarının gelişim çizgisi hakkında bk. (Aça, 2015: 111-137).

3 Türkiye'de hekim folkloruna yönelik ilk bilimsel çalışma, Ezgi Metin'in (2006: 34-38), "Kent Folkloruna Bir Örnek: Doktor Folkloru" başlıklı makalesidir. Yazıda, hekimler arasındaki iletişimi kolaylaştıran deyimler, kalıp ifadeler, kodlar gibi örneklere yer verilmiş, bu grubun iletişimlerini sağlayan terimler jargon kavramı etrafında irdelenmiştir. Bu çalışmanın dışında "Doktor Fıkraları" adıyla yayınlanmış pek çok kitap ve bir makale için bk. (Karataş, 2017: 61-62). 
4 AAMC (Amerikan Tıp Kolejleri Birliği) sağlıkla ilgili herhangi bir mesleği okumak isteyen öğrencilerin girmesi geren MCAT (Tıp Fakültesi Kabul Testi) sınavını geliştirilen ve uygulayan kurumdur (ULR-3).

5 Eric Hobsbawm (2006:1) icat edilmiş geleneği, genellikle açıkça ya da üstü kapalı şekilde kabul görmüş kurallarca yönlendirilen bir dizi uygulama ve kendiliğinden geçmişle sürekliliği olduğunu ima eden, tekrar ile belirli değerler ve davranış kuralları aşılamaya çalışan bir dizi ritüel ya da sembolik yapı olarak tanımlamaktadır. Ünlü tarihçi, Avrupa tarihinde modern dönemde icat edilen gelenekleri uzun bir makalede ele almıştır. Hobsbawm'ın (2006: 305-356) tespitine göre, gelenek icadının en yoğun şekilde gerçekleştiği dönem 1870-1914 arasıdır. Bu bağlamda Beyaz Önlük Giyme Töreni'nde belirtilen icat edilmiş gelenekle ilgili hususlar, modern tıbbın kuruluşunun kutlanması amacıyla icat edilen ve sadece Türkiye'de kutlanan 14 Mart Tıp bayramı için de geçerlidir (Karataş, 2017: 219). Meslek kimliğinin inşası rolüyle dikkat çeken icat edilmiş mesleki geçiş ritlerine örnek olarak, balıkçılar arasında gruba katılım gerçekleştiren yeni üyelerin kabul ve terfî süreçlerine dönük kabulleri de göstermek mümkünüdür. Bugün bazı gırgır teknelerinde takımın bir üyesi olarak daha fazla sorumluluk ve daha yüksek bir statü elde eden katılımcıların bir kova su ile ıslatılması ya da deniz elverişli ise denize atılması gibi şaka temelinde gerçekleştirilen ve daha ziyade sembolik biçimleriyle gözlemlenebilen uygulamalar söz konusudur (Aça, 2020: 230-231). Bunun yanı sıra sonradan icat edilmiş anma ve kutlama törenleri de mevcuttur ki, özellikle modern zamanlarda ulusal kimliğin oluşturulması ve pekiştirilmesi için devletler tarafından bir araç, başka bir ifadeyle "hafıza mekânı" olarak kullanılmaktadır. Her yıl kutlanan ve resmî törenler sırasına giren İstanbul'un fethi etkinlikleri de pek çok hadise gibi modern dönemde ortaya çıkan, bu yönüyle "gelenek icadı" olarak düşünülmesi gereken hadiselerden birisidir (Çoruk, 2016: 79-98).

6 Söz konusu bilgiler, Prof. Dr. Erdem Aydın tarafından 01.04.2021 tarihinde elektronik posta yoluyla bize aktarılmıştır. Aydın, henüz baskıda olduğunu belirttiği Dünya ve Türk Tıp Tarihi adlı kitabının ikinci basımında bu konuya kısa olarak bize anlattıkları çerçevesinde yer verdiğini de belirtmiştir.

7 Çalışma içerisinde bizzat görüşülen kaynak kişiler (KK-1, KK-2, KK-3 ...) şeklinde belirtilmiştir. Kişiler hakkındaki ayrıntılı bilgilere (adı, soyadı, doğum yeri ve tarihi, anabilim dalı, unvanı, görüşme tarihi) yazının sonunda yer verilmiştir.

\section{Kaynaklar}

\section{Sözlü kaynaklar}

KK-1: Ersin Töret, Sivas, 1980, Eskişehir Osmangazi Üniversitesi Tıp Fakültesi Çocuk Sağlı̆̆ı ve Hastalıkları Anabilim Dalı Öğretim Üyesi. (16.02.2021).

KK-2: Koray Harmanc1, Malatya, 1972, Eskişehir Osmangazi Üniversitesi Tıp Fakültesi Çocuk Sağlığı ve Hastalıkları Anabilim Dalı Öğretim Üyesi. (27.02.2021).

KK-3: Kevser Erol, Ayvalık/Balıkesir, 1954, Eskişehir Osmangazi Üniversitesi Tıp Fakültesi Tıbbi Farmakoloji Anabilim Dalı Emekli Öğretim Üyesi. (03.03.2021).

KK-4: Müge İlgüy, Eskişehir, 1992, Eskişehir Osmangazi Üniversitesi Tıp Fakültesi Çocuk Sağl1ğ1 ve Hastalıkları Anabilim Dalı Araştırma Görevlisi Doktor. (06.03.2021).

KK-5: Murat Yağc1, Artvin, 1992, Eskişehir Osmangazi Üniversitesi Tıp Fakültesi Çocuk Sağlığ1 ve Hastalıkları Anabilim Dalı Araştırma Görevlisi Doktor. (07.03.2021).

KK-6: Özge Sürmeli Onay, Samandağ/Hatay, 1980, Eskişehir Osmangazi Üniversitesi Tıp Fakültesi Çocuk Sağlığı ve Hastalıkları Anabilim Dalı Öğretim Üyesi. (08.03.2021).

KK-7: Sümeyye Koç, Trabzon, 1989, Çocuk İmmünolojisi ve Alerji Hastalıkları Bilim Dalı Araştırma Görevlisi Doktor. (11.03.2021).

KK-8: Bahar Ece Tokdemir, Eskişehir, 1992, Eskişehir Osmangazi Üniversitesi Tıp Fakültesi Çocuk Sağlığı ve Hastalıkları Anabilim Dalı Araştırma Görevlisi Doktor. (12.03.2021).

KK-9: Semih Ceylan, Eskişehir, 1999, Eskişehir Osmangazi Üniversitesi Tıp Fakültesi dördüncü sinıf öğrencisi. (12.03.2021).

KK-10: Büşra Bayar, Aksaray, 1997, Eskişehir Osmangazi Üniversitesi Tıp Fakültesi İntörn Doktor. (13.03.2021). 
KK-11: Mehmet Surhan Arda, Ankara/Şereflikoçhisa , 1970, Çocuk Cerrahisi Anabilim Dalı Öğretim Üyesi. (13.03.2021).

KK-12: Gonca Kılıç Yıldırım, Samsun, 1980, Çocuk Beslenme ve Metabolizma Hastalıkları Bilim Dalı Öğretim Üyesi. (14.03.2021).

KK-13: Yıldız Ceylan, Eskişehir, 1969, Eskişehir Osmangazi Üniversitesi Tıp Fakültesi Beyaz Önlük Giyme Töreni’ne katılan ebeveynden biri. (14.03.2021).

KK-14: Huriye Bayar, Doğanhisar/Konya, 1974, Eskişehir Osmangazi Üniversitesi Tıp Fakültesi Beyaz Önlük Giyme Töreni’ne katılan ebeveynden biri. (14.03.2021).

KK-15: İsmail Bayar, Doğanhisar/Konya, 1970, Eskişehir Osmangazi Üniversitesi Tıp Fakültesi Beyaz Önlük Giyme Töreni'ne katılan ebeveynden biri. (14.03.2021).

KK-16: Aslı Kavaz Tufan, Rize, 1978, Eskişehir Osmangazi Üniversitesi Tıp Fakültesi Çocuk Sağlığı ve Hastalıkları Anabilim Dalı Öğretim Üyesi. (15.03.2021).

KK-17: Hilal Kaya Erdoğan, Amasya, 1982, Eskişehir Osmangazi Üniversitesi Tıp Fakültesi Deri ve Zührevi Hastalıklar Anabilim Dalı Öğretim Üyesi. (16.03.2021).

KK-18: Erdem Aydın, İzmir, 1960, Hacettepe Üniversitesi Tıp Fakültesi Deontoloji, Tıp Etiği ve Tıp Tarihi Anabilim Dalı Emekli Öğretim Üyesi. (06.04.2021).

\section{Yazılı kaynaklar}

Aça, M. (2015). Meslek folkloru araştırmaları tarihine bir bakış. Uluslararası Türk Dünyası Kültür Araştırmaları Dergisi, 1(1), 111-137.

Aça, M. (2020). Denizin çocukları. Giresun ve Trabzon yöresi balıkçılarının meslek folkloru. İstanbul: Hiperyayın.

Aydın, E. (2021). Dünya ve Türk tıp tarihi. 2. Basım. Ankara: Güneş Kitabevi. (Baskıda).

Bilgin, N. (2003). Sosyal psikoloji sözlüğü: Kavramlar ve yaklaşımlar. İstanbul: Bağlam.

Büyükokutan Töret, A. (2018). Meslek folkloru kapsamında hekimlerle ilgili stereotipler ve bunlara bağlı şakalar üzerine bir değerlendirme. Motif Akademi Halkbilimi Dergisi, 11 (24), 13-30.

Büyükokutan Töret, A. (2020). Meslek folkloru bağlamında hekimler arasındaki normalar üzerine bir değerlendirme (M. Aça ve M. Dinç. Ed.) Çağdaş yaklaşımlar odağında toplum ve kültür araştırmaları -I içinde (153-184). Çanakkale: Paradigma Akademi.

Bloch, M. (2014). Ritüel, tarih, iktidar (Ü. H. Yolsal. Çev.) Ankara: Dipnot.

Cohen, A. P. (1999). Topluluğun simgesel kuruluşu (M. Küçük. Çev.) Ankara: Dost Kitabevi.

Connerton, P. (2014). Toplumlar nasıl anımsar?. İstanbul: Ayrıntı.

Çilingir Cesur, S. (2020). Hititlerde ritüel ve büyü. İstanbul: VakıfBank Kültür.

Çoruk, A.Ş. (2016). Bir gelenek icadı olarak II. meşrutiyet döneminde gerçekleştirilen İstanbul'un fethi törenleri. Fatih Sultan Mehmet İlmî Araştırmalar İnsan ve Toplum Bilimleri Dergisi, 7, 79-98.

Eriksen, T. H. (2009). Küçük yerler derin mevzular. Sosyal ve kültürel antropolojiye giriş (F. Adsay. Çev.) İstanbul: Avesta.

Gillon, R. (2000). White coat ceremonies for new medical students. Journal of Medical Ethics, 26 (2), 83-84.

Goody, J. (2018). Mit, ritüel ve söz. İstanbul: Küre.

Hobsbawm, E. (2006). Giriş: Gelenekleri icat etmek (M. M. Şahin. Çev.) - ( E. Hobsbawm - T. Ranger. Der.) Geleneğin icadı içinde (1-18). İstanbul: Agora Kitaplığı.

Honko, L. (2006). Ritüellerin oluşum süreci (R. Ersoy. Çev.) Millî Folklor, 69, 129-140. 
Karaman, K. (2010). Ritüellerin toplumsal etkileri. Süleyman Demirel Üniversitesi Fen Edebiyat Fakültesi Sosyal Bilimler Dergisi, 21, 227-236.

Karataş, P. (2017a). İnsanlar ikiye ayrılır: Meslek folkloru bağlamında hekimlik. Ankara: Grafike

Karataş, P. (2017b). Hekim folklorunda stereotiplerin lakapları şekillendirmesi ve fikralara yansımaları. Milli Folklor, 29 (116), 129-142.

Metin, E. (2006). Kent folkloruna bir örnek: Doktor folkloru. Milli Folklor, 18 (71). 34-38.

Örnek, S. V. (2016). Türk halkbilimi. Ankara: BilgeSu.

Özbudun, S. (1997). Ayinden törene. İstanbul: Anahtar Kitaplar.

Rappaport, R. A. (2003). Ritüel. (K. Korkmaz. Çev.) - (G. Öğüt Eker vd. Ed.) Halkbiliminde kuramlar ve yaklaşımlar 1 içinde (396-406). Milli Folklor.

Reiser, S. J. and Ribble J. C. (1995). Oath-taking at medical graduation: The right thing at the wrong time. Academic Medicine, 70 (10), 857-858.

Segal, R. A. (2012). Dinsel mit-ritüel kuram (N. Atabağsoy. Çev.) Millî Folklor, 94, 173-187.

Sönmez, H. M., vd. (2010). Hekimlerin beyaz önlük giymesi hakkında halkın düşünce ve tutumları. İnönü Üniversitesi Tip Fakültesi Dergisi, 17 (1) 1-6.

Schuyt, T.N.M. and Schuijt J.J.M. (1998). Rituals and rules: about magic in consultancy. Journal of Organizational Change Management, 11 (5), 399-406.

Veatch, R. M. (2002). White coat ceremonies: A second opinion. Journal of Medical Ethics, 28 (1), 5-6.

\section{Elektronik kaynaklar}

URL-1:https://www.gold-foundation.org/programs/white-coat-ceremony/ Erişim Tarihi: 21.03.2021.

URL-2:https://www.ps.columbia.edu/education/student-resources/office-student-a fairs/white-coat-ceremony Erişim Tarihi: 21.03.2021.

URL-3:https://worldscholarshipforum.com/tr/what-is-mcat-and-when-to-take-the-mcat/ Erişim Tarihi: 21.03.2021.

URL-4:https://cekmekoyevdenevenakliyat.org/wiki/White_coat_ceremony Erişim Tarihi: 21.03.2021.

URL-5:http://www.eskisehir.gov.tr/tip-fakultesi-ogrencileri-beyaz-onluklerini-giydi Erişim Tarihi: 25.03.2021.

URL-6:https://www.medimagazin.com.tr/hekim/universiteler/tr-eskisehir-osmangazide-birinci-sinifdoktorlar-beyaz-onluk-giydi-2-15-78344.html Erişim Tarihi: 25.03.2021

URL7:https://www.facebook.com/media/set/?set=a.972051616192234.1073741854.17253312614409 1\&type=3 Erişim Tarihi: 25.03.2021

URL-8:https://tip.ogu.edu.tr/Haber/Detay/18/beyaz-onluk-giyme-toreni Erişim Tarihi: 26.03.2021

Warren, P. M. (1999). For new medical students, white coats are a warmup. Los Angeles Times, October 18, Erişim Tarihi: 21.03.2021, https://www.latimes.com/archives/la-xpm-1999-oct-18-me-23619story.html

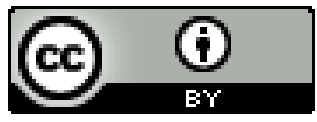

$\mathrm{Bu}$ eser Creative Commons Atıf 4.0 Uluslararası Lisansı ile lisanslanmıştır. (This work is licensed under a Creative Commons Attribution 4.0 International License). 


\section{Fotoğraflar}

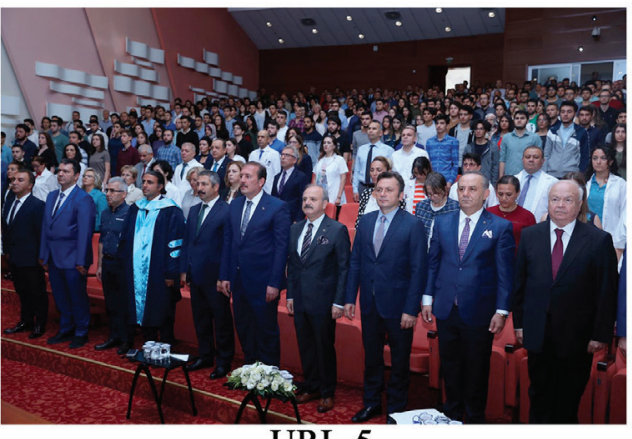

URL-5

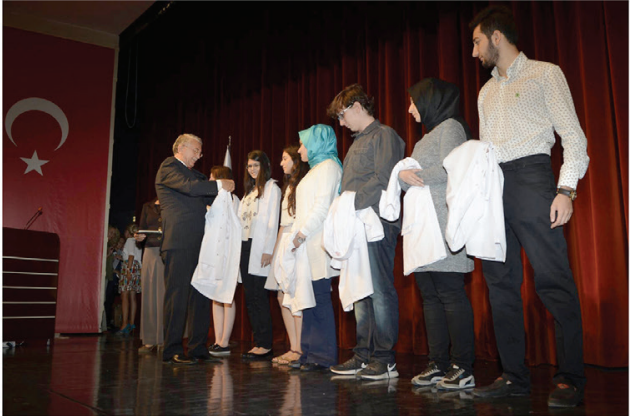

URL-7

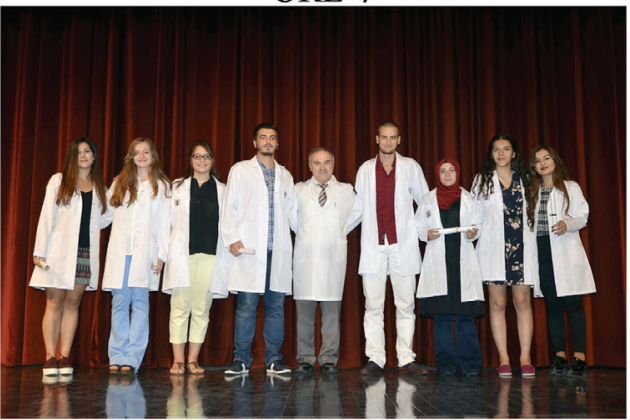

URL-7

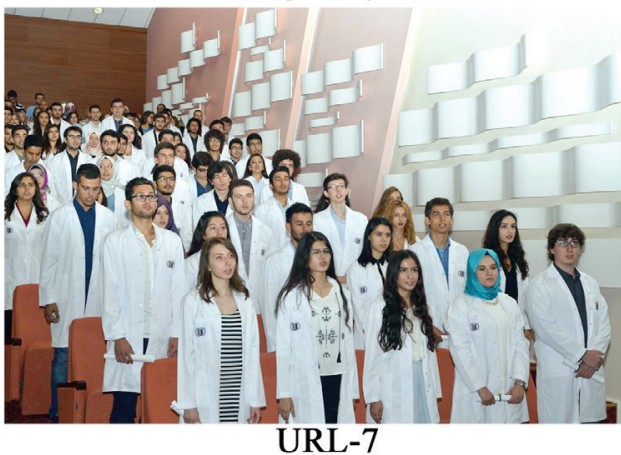

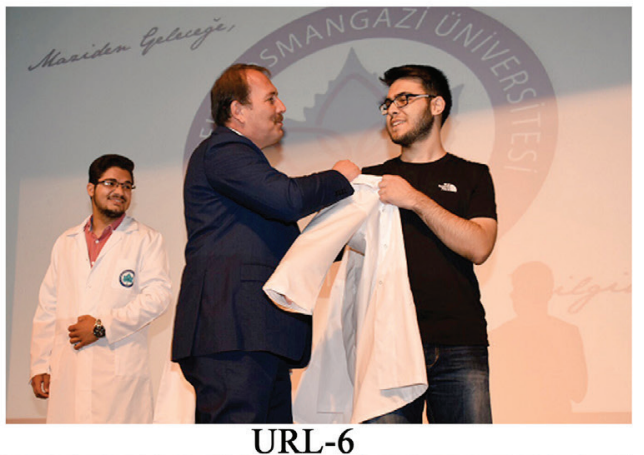

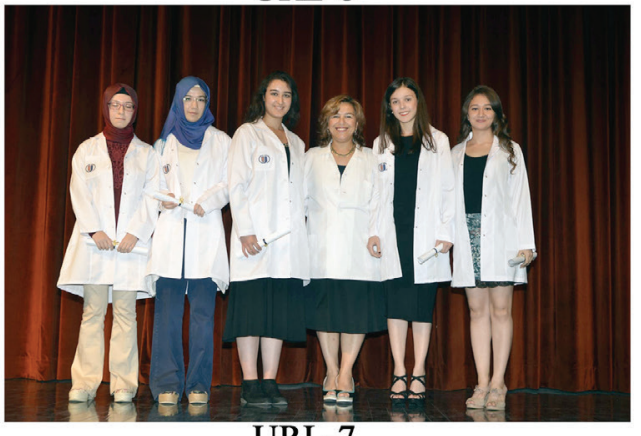

URL-7

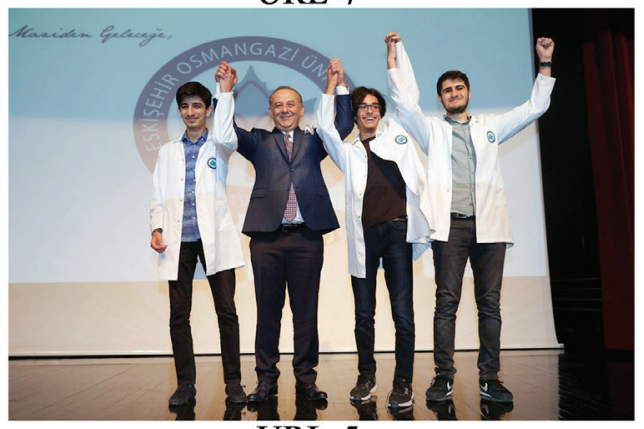

URL-5

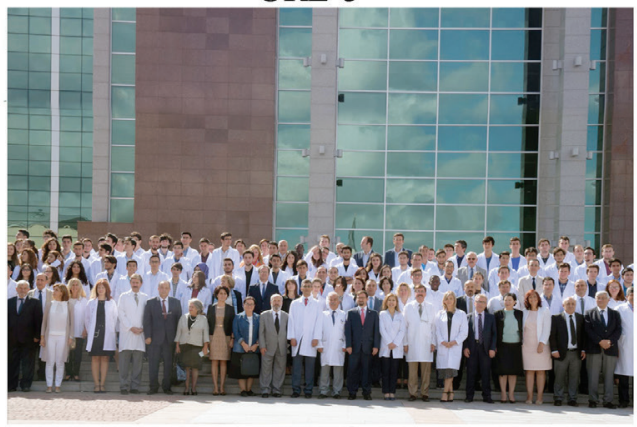

URL-8 
T.C.

ESKIȘEHIR OSMANGAZI ÜNIVERSITESI

SOSYAL VE BEŞERI BILIMLER

INSAN ARAŞTIRMALARI ETIK KURULU

ESKIŞEHIR

Toplantı Tarihi : 26.03.2021

Toplantı No : 2021-06

\title{
GÜNDEM :
}

12. Başvuru Sahibi : Doç.Dr.Aslı BÜYÜKOKUTAN TÖRET. Konu : "Hekimlik Mesleğine Ilk Geçiș Ritüeli : Beyaz Önlük Giyme" konulu araştırmasının görüşülmesi.

\section{KARAR :}

12. Doç.Dr.Aslı BÜYÜKOKUTAN TÖRET'in "Hekimlik Mesleğine ilk Geçiş Ritüeli : Beyaz Önlük Giyme" konulu araştırmasının ve başvuru evrağının ekinde örneği bulunan araştırmasında kullanacağı ölçme aracını/araçlarının; fikri, hukuki ve telif hakları bakımından metot ve ölçeğine ilişkin sorumluluk başvuru sahibine ait olmak üzere veri toplama araçlarımı uygulamak için gerekli yerlerden yasal izinleri almak şartıyla Üniversitemiz insan araştırmaları etik kurulu yönergesine uygunluğuna oybirliği ile karar verildi.

\author{
(imza) \\ Prof. Dr. Yaşar SARI \\ Başkan
}

(İmza)

Prof. Dr. Esra DERELi

Bașkan Yardımcısı

(imza)

Prof. Dr. Zafer BALBAĞ

Üye

(imza)

Prof.Dr. Birol YILDIZ

Üyc
(İmza)

Prof. Dr. Ferit USLU

Üye

(Imza)

Prof. Dr.Ayşe AYPAY

Üye

(İmza)

Prof.Dr. Mustafa Kemal BEŞER

Üye (Raportör) 